\title{
NOTICE COST PROBLEMS UNDER RULE \\ 23(b)(3) AND (c)(2) AFTER OPPENHEIMER FUND, INC. V. SANDERS
}

Ordinarily, the plaintiffs im Rule $23(\mathrm{~b})(3)^{1}$ class actions must bear the initial cost of $(c)(2)^{2}$ notice to the class. ${ }^{3}$ Based on the assumption that high notice costs discourage potential (b)(3) plamtiffs from bringing claims that are otherwise well-suited for class action status, nuinerous approaches have been suggested that would eliminate or minimize this cost burden. ${ }^{4}$ An analysis of these approaches in hight of the Supreme Court's recent decision in Oppenheimer Fund, Inc. v. Sanders ${ }^{5}$ reveals that each has serious limitations and that, collectively, the various approaches will afford little relief to (b)(3) plaintiffs seeking to minimize the burden of (c)(2) notice costs. A recent proposal by a division of the Uinted States Department of Justice would replace the (b)(3) and

\section{THE FOLLOWING CITATIONS WILL BE USED IN THIS NOTE:}

S. 3475, 95th Cong., 2d Sess., reprinted in Reform of Class Action Litigation Procedures: Hearings on $S .3475$ Before the Subcomm. on Improvements in Judicial Machinery of the Senate Comm. on the Judiciary, 95th Cong., 2d Sess. 265 (1978) [hereinafter cited as S. 3475];

Advisory Committee's Note to Proposed Rule 23, in Judicial Conference of the UNITED States, Proposed Amendments to Rules of Civil Procedure for the United States DisTRICT CouRTs (1966), reprinted in 39 F.R.D. 98 (1966) [hereinafter cited by F.R.D. page number as Advisory Comm. Note].

1. FED. R. Crv. P. 23(b)(3) provides:

(b) Class Actions Maintainable. An action may be maintained as a class action if the prerequisites of subdivision (a) are satisfied, and in addition:

(3) the court finds that the questions of law or fact common to the inembers of the class predouninate over any questions affecting only individual meinbers, and that a class action is superior to other available methods for the fair and efficient adjudication of the controversy. The matters pertiment to the findings mclude: $(A)$ the interest of meinbers of the class in individually controlling the prosecution or defense of separate actions; (B) the extent and nature of any litigation concerning the controversy already commenced by or agaimst members of the class; (C) the desirability or undesirability of concentrating the litigation of the claims in the particular forum; (D) the difficulties likely to be encountered in the managenent of a class action.

2. FED. R. CIv. P. 23(c)(2) provides:

In any class action maintained under subdivision (b)(3), the court shall direct to the members of the class the best notice practicable under the circumstances, including individual notice to all members who can be identified through reasonable effort. The notice shall advise each member that (A) the court will exclude hin from the class if he so requests by a specified date; (B) the judgment, whether favorable or not, will include all members who do not request exclusion; and $(C)$ any meinber who does not request exclusion may, if he desires, enter an appearance through his counsel.

3. Eisen v. Carlisle \& Jacquelin, 417 U.S. 156, 178-79 (1974).

4. See text accompanying notes 25-32 infra.

5. 437 U.S. 340 (1978). 
(c)(2) class action scheme with radically different procedures, ${ }^{6}$ but the proposed notice provisions fail to deal with some of the cost problems posed by current interpretations of subdivisions (b)(3) and (c)(2). ${ }^{7}$ After a brief summary of the background of the notice cost problem, this Note will analyze the impact of Oppenheimer on the various approaches for dealing with (c)(2) notice costs and will address the shortcomings of the Department of Justice's proposed notice provisions.

\section{The Notice Cost Problem: Background}

When the present version of Rule 23 was adopted in 1966, the Advisory Committee noted that subdivision (b)(3) was imtended to encompass "those cases in which a class action would achieve economies of time, effort, and expense, and promote uniformity of decision as to persons similarly situated ...." This concern with economy and uniformity, however, was to be achieved "without sacrificmg procedural fairness or bringing about other undesirable results." More importantly, unlike the old rule, subdivision (b)(3) was to provide a vehicle for litigating the claims of inembers of a class of similarly situated persons, and for binding the members of the class im a simgle lawsuit, even though different questions affected individual members. ${ }^{10}$ At the same time, however, the drafters of the rule recognized that even where subdivision (b)(3) provides a suitable method for redressing the injuries of an entire class, individual members might wish to pursue their own claims. ${ }^{\text {II }}$ Subdivision (c)(2) therefore provides that a class member has the right to be excluded from the class on his request. ${ }^{12}$ To protect this right to be excluded, subdivision (c)(2) provides that in (b)(3) actions, "the court shall direct to the inembers of the class the best notice practicable under the circumstances, includimg individual notice to all members who can be identified through reasonable effort." 13

The subdivision (c)(2) notice requirements soon generated substantial controversy, particularly with regard to the form of notice and the question of who was to bear the cost of sending the notice to the

6. See Office for Improvements in the Administration of Justice, U.S. Dep't of Justice, Effective Procedural Remedies for UnLawful Conduct Causing Mass EcoNOMIC INJURIES (1977) (draft statute with comment); $c f$ S. 3475 (modified version of OIAJ proposal). See text accompanying notes $158-78$ infra.

7. See text accompanying notes 179-83 infra.

8. Advisory Comm. Note 102-03.

9. Id. 103 .

10. See FeD. R. Civ. P. 23(b)(3); Advisory Comm. Note 103.

11. Advisory Comm. Note 104-05.

12. FED. R. Civ. P. 23(c)(2).

13. Id. 
members of the class. ${ }^{14}$ The Supreme Court confronted this controversy in Eisen v. Carlisle \& Jacquelin. ${ }^{15}$ Eisen, whose individual stake in the damages was only $\$ 70,{ }^{16}$ sought to represent a class with six million members. ${ }^{17}$ The names and addresses of over two million meinbers could be obtained from the defendants' records. ${ }^{18}$ Eisen argued unsuccessfully that notice by publication would satisfy the requirements of subdivision (c)(2) and that, $m$ any event, the defendant should bear the cost of notice. The Court concluded that in (b)(3) class actions, "individual notice must be provided to those class members who are identifiable through reasonable effort," 19 even though the cost of such notice to the two million identifiable members would be in excess of $\$ 300,000{ }^{20}$ "The usual rule [said the Court] is that a plaintiff must initially bear the cost of notice to the class." 21

The impact of the Eisen decision is difficult to measure. Some courts and commentators have suggested that the decision has had little impact at all, and that (b)(3) claims are as numerous now as before the decision. ${ }^{22}$ These observers argue that the costs of notice are not so

14. See, e.g., Ostapowicz v. Johnson Bronze Co., 54 F.R.D. 465 (W.D. Pa. 1973) (court divided notice cost equally between plaintiff and defendant); Battle v. Municipal Hous. Auth., 53 F.R.D. 423 (S.D.N.Y. 1971) (court imposed notice cost on defendant); Cohen v. Franchard Corp., 51 F.R.D. 167 (S.D.N.Y. 1970) (court imposed notice cost on plaintiff), affd on other grounds, 478 F.2d 115 (2d Cir. 1973); Knight v. Board of Educ., 48 F.R.D. 108 (E.D.N.Y. 1969) (court sent out notice at its own expense and on court stationery).

15. 417 U.S. 156 (1974). Several of the opinions in the Eisen litigation are relevant to the discussion herein. The reported history of Eisen is as follows: Eisen v. Carlisle \& Jacquelin, 41 F.R.D. 147 (S.D.N.Y.), appeal allowed, 370 F.2d 119 (2d Cir. 1966) (Eisen I), cert. denied, 386 U.S. 1035 (1967), rev'd and remanded while retaining jurisdiction, 391 F.2d 555 (2d Cir. 1968) (Eisen II), on remand, 50 F.R.D. 471 (S.D.N.Y. 1970), 52 F.R.D. 253 (S.D.N.Y. 1971), 54 F.R.D. 565 (S.D.N.Y. 1972), rev'd, 479 F.2d 1005 (2d Cir. 1973) (Eisen III), vacated and remanded, 417 U.S. 156 (1974) (Eisen IV or Eisen). Subsequent citations to one or more of the Eisen opinions appear without the accompanying case history.

16. 417 U.S. at 161 .

17. Id. at 166.

18. Id.

19. Id. at 175.

20. Id. at 167 n.7.

21. Id. at 178. The Court specifically rejected the use of a preliminary "mini-hearing" into the merits to determine who should bear the cost of (c)(2) notice, reasoning that such a procedure was not authorized by Rule 23. Id. at 177-78. The rationales of the Supreme Court and of the circuit court decision that it affirmed, 479 F.2d 1005 (2d Cir. 1973), have been widely criticized. See, e.g., 2 H. Newberg, Class Actions § 2300a (1977); Dam, Class Action Notice: Who Needs It?, 1974 Sup. CT. Rev. 97; Note, Managing the Large Class Action: Eisen v. Carlisle \& Jacquelin, 87 HaRv. L. Rev. 426, 433, 440 (1973); Note, The Manageability Crisis of Consumer Class Actions: The Severe Example of Eisen III, 7 1ND. L. REv. 361, 389 (1973); 16 B.C. INDus. \& CoM. L. Rev. 254, 265-66 (1975); 73 Colum. L. Rev. 1641, 1654 (1973); cf. Note, Class Actions Under Federal Rule 23(b)(3)-The Notice Requirement, 29 MD. L. REv. 139 (1969) (pre-Eisen discussion of notice requirement).

22. See, e.g., Sanders v. Levy, 558 F.2d 636, 646, 655 n.6 (2d Cir. 1977) (en banc) (Mulligan, 
high that plaintiffs have been discouraged from utilizing the procedural benefits of subdivision (b)(3). ${ }^{23}$ On the other hand, it is impossible to determine how many plaintiffs imight have brought $(b)(3)$ actions but for the cost of notice to the class. Where a plaimtiff represents a large class of injured persons who have in the aggregate suffered substantial damages, but whose individual claims are too small to support individual causes of action, that plaintiff's reluctance to pay for notice, the cost of which might amount to hundreds of thousands of dollars, would be understandable. Thus, by placing on (b)(3) plaintiffs the cost of the initial notice required by subdivision (c)(2), the Eisen decision has, as a practical matter, limited the availability of a class action for pursuing federal claims im precisely the situation im which the damaged persons are least likely to pursue their claims imdividually. ${ }^{24}$

The Eisen decision, then, raises the question of how potential (b)(3) plaintiffs can minimize or avoid the burden of notice costs. Several important possibilities exist, each of which will be addressed below. ${ }^{25}$ First, some plaimtiffs have sought to distinguish the costs of

C.J., dissenting), rev'd and remanded sub nom. Oppenheimer Fund, Inc. v. Sanders, 437 U.S. 340 (1978); 5 Class ACT. Rep. 133, 237 (1978).

23. See sources cited at note 22 supra.

24. See 124 Cong. Rec. S14,501, S14,502 (daily ed. Aug. 25, 1978) (bill commentary to S. 3475); 124 CoNG. REC. S33 (daily ed. Jan. 19, 1978) (remarks of Sen. Metzeubauin); Lyons, Class Actions, 1974/75 ANN. Survey AM. L. 349, 356; 16 B.C. Indus., supra note 21, at 264; $c f$ Zahn v. International Paper Co., 414 U.S. 291 (1973) (requiring each class member to satisfy the jurisdictional amount requirement). For similar conclusions in response to the decisions in Eisen $I I$ and Eisen III, see Eisen v. Carlisle \& Jacquelin, 479 F.2d 1005, 1022-25 (2d Cir. 1973) (Eisen III) (Oakes, C.J., dissenting from denial of reliearing en banc); Pomerantz, New Developments in Class Actions-Has Their Death Knell Been Sounded?, 25 Bus. LAw. 1259, 1263 (1970) (commenting on Eisen $I I)$.

25. Several suggestions for deahing with the notice cost problem lave been made that, because of various shortcomings, have had little impact on class action litigation. One such suggestion was the organization of a Public Equity Corporation (PEC), which liad as its business purpose the financing of class action litigation for a profit. See 4 Class ACT. REP. 308 (1975). The PEC concept was apparently abandoned after the initial stock offering failed for lack of investor interest. Id. 341. Another suggestion was that charitable foundations or consumer groups could donate notice costs, to be reimbursed from any recovery received by the plaintiffs. See Colien, Reflections on Supreme Court Arguments-Eisen v. Carlisle \& Jacquelin, N.Y.L.J., Mar. 25,1974 , at 1 , col. 1. At least one organization exists that provides financial assistance in class action suits, but plaintiffs are generally limited to assistance under $\$ 5,000$. See 5 Class. AcT. REP. 305 (1978); cf. Note, The Rule 23(b)(3) Class Action: An Empirical Study, 62 Geo. L.J. 1123, 1160 (1974) (study results indicate that, on a national basis, $35 \%$ of (b)(3) class actions involve notice costs in excess of $\$ 5,000)$.

Soine commentators liave suggested that subdivisions (b)(1) and (b)(2) of Rule 23 inight be used as alternatives to (b)(3), see e.g., 2 H. NEwBERG, supra note 21 , at $\$ 2425 \mathrm{~d}$, at 106-08, since notice is discretionary for actions qualifying under those subdivisions. See FED. R. CIV. P. 23(d)(2). While (b)(1) actions can involve clainus for monetary relief, see, e.g., Zachary v. Chase Manhattan Bank, 52 F.R.D. 532 (S.D.N.Y. 1971), the focus in such actions is on the legality of the ongoing or imminent conduct of the party opposing the class. Actions under subdivision (b)(3) 
identifying class inembers from costs of printing and inailing the notice, with the forner treated as a discovery cost that can be imposed upon the defendant. ${ }^{26}$ Second, notwithstanding the usual rule with regard to the cost of (c)(2) notice, Justice Powell, in his opimion for the Eisen majority, left open the possibility that a preexisting fiduciary relationship between the plaintiff and the defendant might support imposing notice costs on the defendant. ${ }^{27}$ Third, the plaintiff's counsel inight advance the cost of (c)(2) notice and aid in the solicitation of funds from absentee class ineinbers. ${ }^{28}$ Finally, Justice Douglas suggested in Eisen that the (c)(2) notice cost burden might be lessened under subdivision (c)(4)-which provides for the division of a class into subclasses ${ }^{29}$-by treating one subclass as a test case. ${ }^{30}$ Similarly, the Third Circuit decided shortly before Eisen that a plaintiff's individual claim inight be tested in a test case before certification of the class. ${ }^{31}$ If the plaimtiff's claim failed, no notice to the class would be necessary; if it were successful, the cost of notice could be imposed on the defendant. $^{32}$

\section{OPPENheimer and Costs OF IDENTIFying Class Members}

After Eisen established that ordinarily the plaintiff imitially inust bear the cost of (c)(2) notice, the question of what was meant by notice

focus on the redress of individual class members for conduct already concluded. See Bennett, Eisen v. Carlisle \& Jacquelin: Supreme Court Calls for Revamping of Class Action Strategy, 1974 WIS. L. REv. 801, 817-18. Even if a damage action is permitted under subdivision (b)(1), the court is likely to require notice to absentee members of the class. See, e.g., Zachary v. Chase Manhattan Bank, 52 F.R.D. 532 (S.D.N.Y. 1971); Bennett, supra at 817-18; cf. 7A C. WRIGHT \& A. Miller, Federal Practice aNd Procedure \& 1793 (1972 \& Supp. 1978) (giving some type of notice in (b)(1) actions is the best practice in most cases). Subdivision (b)(2) of Rule 23 applies to class actions for declaratory or injunctive relief, not actions for money damages. Notice may still be required, however. See, e.g., Souza v. Scalone, 563 F.2d 385 (9th Cir. 1977), Eley v. Morris, 390 F. Supp. 913 (N.D. Ga. 1975); 7A C. WRIGHT \& A. Miller, supra at $\$ 1793$. Where an action involves both $(b)(2)$ and $(b)(3)$ aspects and the court determines that no notice is necessary as to the (b)(2) portion of the case, the court might subdivide the action to mininize (c)(2) notice costs. See, e.g., Freeman v. Motor Convoy, Inc., 68 F.R.D. 196 (N.D. Ga. 1974), motion for rehearing denied, 68 F.R.D. 204 (N.D. Ga. 1975).

26. See text accompanying notes 33-38 infra.

27. 417 U.S. at $178 \&$ n.15. See text accompanying notes $65-67$ infra.

28. See text accompanying notes $90-96$ infra.

29. FED. R. Civ. P. 23(c)(4) provides:

When appropriate (A) an action may be brought or maintained as a class action with respect to particular issues, or (B) a class may be divided into snbclasses and eacli subclass treated as a class, and the provisions of this rule shall then be construed and applied accordingly.

30. 417 U.S. at 179-81 (Douglas, J., dissenting in part and concurring in part). See text accompanying notes 124-36 infra.

31. Katz v. Carte Blanche Corp., 496 F.2d 747 (3d Cir.), cert. denied, 419 U.S. 885 (1974).

32. 496 F.2d at 761. See text accompanying notes 138-42 infra. 
becaine a special concern for the plaintiff seeking to minimize the notice cost burden. Where the naines and addresses of the absentee meinbers were contained in the records of the defendant or a nonparty to the class action, the question was whether the costs of identifying the absentees was a cost of notice, and thus a cost to be borne by the plaintiff. The Oppenheimer decision has inade it clear that in (b)(3) class actions, identification of class nembers is part and parcel of (c)(2) notice.

\section{A. Identification from the Defendant's Records.}

Oppenheimer addressed a conflict between two circuits over the treatinent of identification costs where the information was contained in the records of a party or of someone controlled by a party opposing the class action. ${ }^{33}$ The central issue dividing the two circuits was the

33. See Sanders v. Levy, 558 F.2d 636, 646 (2d Cir. 1977) (en banc) (records kept by defendant's transfer agent that, although not a party to the action, was controlled by a party), rev'd and remanded sub nom. Oppenheimer Fund, Inc. v. Sanders, 437 U.S. 340 (1978); In re Nissan Motor Corp. Antitrust Litigation, 552 F.2d I088 (5th Cir. 1977) (records kept by the defendant). For discussions of the circuit court decisions in Sanders and Nissan, see Note, Allocation of Identification Costs in Class Actions: Sanders v. Levy, 91 HARv. L. Rev. 703 (1978); 66 CAL. L. Rev. 105 (1978).

Before Nissan and the lower courts' decisions in Oppenheimer, the question of whether (c)(2) notice included identification of class members did not receive much attention by courts or litigants. Before Eisen, several trial courts imphicitly distinguished costs of identification from costs of printing and mailing notice, imposing the former costs on defendants and the latter on plaintiffs; in each case, the identification was made from records in the possession of the corporate defendant. See, e.g., Richardson v. Hamilton Int'1 Corp., 62 F.R.D. 413 (E.D. Pa. 1974); Lamb v. United Security Life Co., 59 F.R.D. 25 (S.D. Iowa 1972); Berland v. Mack, 48 F.R.D. 121 (S.D.N.Y. 1969); Contract Buyers League v. F \& F Inv., 48 F.R.D. 7 (N.D. Ill. 1969); $c f$. Herbst v. I T \& T Corp., 65 F.R.D. 13, 19-20 (D. Conn. 1973) (where names and addresses of absentee class members were contained in defendants' computer tapes, defendants were ordered to provide plaintiff with "the requisite materials in their possession" to "facilitate and expedite tle plamtiffs task" of notice), affd, 495 F.2d 1308 (2d Cir. 1974); Herbst v. Able, 47 F.R.D. 11, 18 (S.D.N.Y. 1969) (defendant ordered to "supply such material in its possession to plaintiffs' attorneys as will help enable them to locate" the absentee members of the class for purposes of (c)(2) notice), modified on other grounds, 49 F.R.D. 286 (S.D.N.Y. 1970). In Berland, however, plaintiff and defendants alike wanted the underlying suits declared class actions. 48 F.R.D. at 132-33. In Appelton Elec. Co. v. Advance-United Expressways, 494 F.2d 126 (7th Cir. 1974), an action to compel refunds of illegal rate increase, the common carrier defendants in bad faith failed to keep adequate records to facilitate identification of class members. Id. at 135 . Several additional decisions did not place the burden of identification clearly on either plamtiff or defendant; the identification process did not appear to be difficult and the issue of costs vis-a-vis notice was not raised. See, e.g., B \& B lnv. Club v. Klemert's, Inc., 62 F.R.D. 140, 145 (E.D. Pa. 1974); Cohen v. Francliard Corp., 51 F.R.D. 167, 175 (S.D.N.Y. 1970), affd on other grounds, 478 F.2d 115 (2d Cir. 1973); Korn v. Franchard Corp., 50 F.R.D. 57, 59 (S.D.N.Y. 1970); Harris v. Jones, 41 F.R.D. 70,74 n.8 (D. Utah 1966). The one case in which a court squarely held that the plaintiffs must bear costs of identification was an antitrust civil damages action brought by several states as parens patriae. In re Antibiotic Antitrust Actions, 333 F. Supp. 278 (S.D.N.Y.), aff'd per curiam sub nom. Pfizer, Inc. v. Lord, 449 F.2d 119 (2d Cir. 1971). 
applicability of the discovery rules ${ }^{34}$ to identification of absentee class members. ${ }^{35}$ In both cases, the plaintiffs urged that the discovery rules provided the proper standards for identifying the absentee nembers from the defendants' records. ${ }^{36}$ Under the discovery rules, the defendants normally would have to bear the cost of compiling from their records a list of the names and addresses of class members. ${ }^{37}$ Rule 26(c) would authorize the court to protect the respondimg defendants from undue burden or expense. ${ }^{38}$

The Oppenheimer Court held that Rule 23(c), not the discovery rules, governs the identification issue; subdivision (d) of the rule provides the trial court with discretion in dealing with identification. ${ }^{39}$ The Court reasoned that "[t]he critical point is that the mformation is sought to facilitate the sending of notice rather than to define or clarify

Following Eisen, but before Nissan and Oppenheimer, the identification question continued to receive sketchy treatment. Soine courts imposed identification costs on the corporations whose records contained the information, but did not analyze the scope of the terin "notice" in subdivision (c)(2). See, e.g., City of New York v. Darling-Delaware, Inc., [1976-1] Trade Cas. \60,812 (S.D.N.Y.); Hawkins v. Holiday Inns, Inc., 19 Fed. R. Serv. 2d 1322 (W.D. Tenn. 1975); Foster v. Maryland State Sav. \& Loan Ass'n, [1974-2] Trade Cas. If 75,277 (D.D.C.). Other courts placed the identification burden on plaintiffs, still without an analysis of "notice." See, e.g., In re Sugar Indus. Antitrust Litigation, 73 F.R.D. 322 (E.D. Pa. 1976); In re United States Financial Sec. Litigation, 69 F.R.D. 24 (S.D. Cal. 1975).

This erratic line of precedent for the identification costs problem suggests that in many cases such costs are not substantial enough to warrant litigating the question of who should pay. Clearly, however, identification costs are substantial in soune cases. See, e.g., Oppenheiuner Fund, lnc. v. Sanders, 437 U.S. at 345 ( $\$ 16,000$ cost of identification); Chevalier v. Baird Sav. Ass'n, 72 F.R.D. 140 (E.D. Pa. 1976) (\$14,500 cost of identification). It should be noted that in Oppenheimer the names and addresses of the class members were contained in computerized records of a defendant's transfer agent; the $\$ 16,000$ cost of designing a prograin to obtain the names and addresses from those records was the focal point of the dispute. 437 U.S. at 345 . In Nissan, identification of the absent class inembers required exainination of 1.7 milhon cards of the defendant. 552 F.2d at 1094. For the would-be (b)(3) plaintiff seeking to represent a large class of persons whose aggregate dainages are substantial, but whose individual clains are small, the cost of identifying absentee members, when added to the cost of printing and mailing the notice, might place the cost of the suit beyond that plaintiffs financial resources. See Chevalier v. Baird Sav. Ass'n, 72 F.R.D. at 148; Bernstein, Issues Becoming More Sophisticated as Class Action Litigation Continues, N.Y.L.J., Dec. 19, 1977, at 50, col. 4.

34. FED. R. CIV. P. 26-37.

35. See Sanders v. Levy, 558 F.2d 636, 648 (2d Cir. 1977) (en banc) ("the information sought by plaintiffs as to the names and addresses of the members of the class is indeed within the broad scope of permissible discovery established by our Federal Rules"), rev'd and remanded sub nom. Oppenheimer Fund, Inc. v. Sanders, 437 U.S. 340 (1978); In re Nissan Motor Corp. Antitrust Litigation, 552 F.2d 1088, 1102 (5th Cir. 1977) (discovery rules do not "provide a proper model for analyzing this problein").

36. 437 U.S. at $350 ; 552$ F.2d at 1100 .

37. Fed. R. Civ. P. 26(b)(1).

38. FED. R. Civ. P. 26(c).

39. 437 U.S. at $342,350$. 
issues in the case."40 The Court rejected the contention of the corporate defendants "that Eisen $I V$ always requires a representative plaintiff to pay all costs incident to sending notice, whether he or the defendant performs the required tasks." ${ }^{41}$ Still, the Court reasoned that

a district court exercising its discretion under Rule 23(d) should be considerably more ready to place the cost of the defendant's performing an ordered task on the representative plaintiff, who derives the benefit, than under Rule 26(c). In the usual case, the test should be whether the expense is substantial, rather than, as under Rule 26(c), whether it is "undue."42

In language reseinbling that of Eisen, the Court stated that "[ $t]$ he general rule must be that the representative plaintiff should perform the tasks" ${ }^{43}$ relating to class notice, including identification of class members and that "ordinarily there is no warrant for shifting the cost . . . of these tasks to the defendant."44 The Court left open the possibility that where the defendant could "perform a necessary task with less difficulty or expense than could the representative plaintiff,"45 a district court might properly order the defendant to perform the task; in doing so, the Court acknowledged that a limited analogy could be drawn from practice under the discovery rules. ${ }^{46}$ In the Court's view, however, such an "analogy necessarily is imperfect . . . because $m$ the Rule 23(d) context, the defendant's own case rarely will be advanced by his having performed the tasks." 47 Noting that the cost of identification would be the same for either party, the Court imposed the cost on the

\section{Id. at 350 .}

If respondents had sought the information because of its relevance to the issues, they would not have been willing, as they were, to abandon their request if the District Court would accept their proposed redefinition of the class and method of sending notice. $\mathrm{Re}-$ spondents argued to the District Court that they desired this information to enable them to send the class notice, and not for any other purpose.

Id. at 353. See FED. R. Civ. P. 26(b)(1). By contrast, the en banc majority of the circuit court concluded that "[t]he holding of Eisen $I V$ itself propels us ineluctably to the conclusion that the names and addresses of class members are 'relevant to the subject matter' of a class action." 558 F.2d at 648 .

41. 437 U.S. at 356. In Nissan, the corporate defendants argued that (b)(3) plaintiffs, as fiduciary representatives of the absent class members, must always pay notification costs. 552 F.2d at 1102 . While the Nissan court expressly reserved any ruling on the merits of this fiduciary approach, see id., the Supreme Court's language in Oppenheimer clearly rejects the Nissan defendants' characterization of plaintiffs' obligation with respect to identifying absent class members. 437 U.S. at $356-57$.

42. 437 U.S. at $358-59$.

43. Id. at 356.

44. Id.

45. Id.

46. Id. at 356-57.

47. Id. at 358 . 
representative plaintiff. ${ }^{48}$

The Oppenheimer Court's resolution of the identification cost issue poses several problems. First, it will not always be clear whether identification of absent class ineinbers is strictly a part of the (c)(2) notice process or relates to the subject matter of the pending litigation. ${ }^{49} \mathrm{Be}-$ cause the identification process is one of gathering information, it bears a strong resemblance to discovery. Indeed, the Oppenheimer Court conceded that the names and addresses of absent class inembers might, in some cases, be obtained under the discovery rules. ${ }^{50}$ The absentees, for example, miglit possess information that would assist the representative plaintiffs in their conduct of the litigation..$^{51}$ But the Court's admonition that "it may be doubted whether any of these purposes would require compilation of the naines and addresses of all members of a large class," $" 52$ suggests that it will be a rare case in which a (b)(3) plaintiff will be able to obtam through discovery the names and addresses of class members.

A second problein is raised by the suggestion in Oppenheimer that district courts liave some discretion to allocate the tasks and the cost of identification between plaintiff and defendant. ${ }^{53}$ Eisen foreclosed the use of any prelimmary imquiry into the merits of an action as a ineans of allocating notice costs between plaintiff and defendant. ${ }^{54}$ If burdening a defendant witli the performance or expense of identification is contimgent upon a determination that the defendant's case will be advanced, ${ }^{55}$ district courts might well refuse to make such a determmation to avoid running afoul of Eisen. ${ }^{56}$

The most important consequence of the Oppenheimer decision is that it will add to the cost burden of would-be class representatives in (b)(3) actions where the names and addresses of the class members are contained in the records of a party opposing the class. After Oppenheimer, defendants im (b)(3) actions certainly will succeed in imposing

48. Id. at 360 .

49. Indeed, in Oppenheimer itself, the en banc majority of the circuit court concluded that the names and addresses of the absent class members were relevant to the subject matter of (b)(3) class actions. 558 F.2d at 648 .

50. 437 U.S. at 354 n.20.

51. Id.

52. Id.

53. Id. at $342,350,359$. See text accompanying notes $4 \mathrm{I}-48$ supra.

54. 417 U.S. $177-78$.

55. See 437 U.S. at 358.

56. Cf. Popkin v. Wheelabrator-Frye, Inc., 20 Fed. R. Serv. $2 d 125$ (S.D.N.Y. 1975) (the court read Eisen's rejection of a preliminary inquiry to preclude any allocation of notice costs between plaintiff and defendant, notwithstanding a suggestion in Eisen that such allocation might be appropriate in some circumstances). 
identification costs on plaintiffs, even if the task is concomitant to discovery. Indeed, the Court's suggestion that "in soine instances, the expense involved may be so insubstantial as not to warrant the effort required to calculate it and shift it to the representative plaintiff,"57 indicates that where a (b)(3) plaintiff most needs rehef from costs of identification, he will be least likely to obtain it, at least at the expense of the defendant..$^{58}$

\section{B. Identification from the Records of a Nonparty.}

The Oppenheimer decision also affects the problem posed when the information needed to identify absentee class members is in the records of someone not a party and not controlled by a party to the class action litigation. ${ }^{59}$ This problem has arisen where stock is held in street name by a broker for the beneficial owners, who are members of the plaintiff class. ${ }^{60}$ The courts that have addressed the question have concluded that the proper method for obtaining the names and addresses of the beneficial owners is by subpoenas duces tecum: the court issumg the subpoena would have power under Rule 26(c) to deal with questions about the expense of providing the requested information. ${ }^{61}$ Under this approach, the cost to the nonparty broker is treated as a normal business, expense where the cost to the broker is modest and the total cost of identification would be burdensome to the plaintiff if he had to pay the costs of all the brokers who were requested to produce the names and addresses of the defendant's shareholders. ${ }^{62}$

After the Oppenheimer decision, lowever, there can be little doubt that the plaintiff should normally bear the costs of identifying absentee class members whose shares are held in street name. Oppenheimer makes it clear that identification of class members is part of a (b)(3) plaintiff's obligations under subdivision (c)(2). ${ }^{63}$ If defendants would

57. 437 U.S. at 359.

58. Presumably, where a defendant has in bad faith made it more difficult for the plaintiff to obtain the names and addresses of absentee members, the defendant could be made to bear even substantial costs. See Appelton Elec. Co. v. Advance-United Expressways, 494 F.2d 126, 135-37 (7th Cir. 1974).

59. In Oppenheimer, the records containing the names and addresses of the absentee class members were kept by the defendant fund's transfer agent, which was not a party to the action. See 437 U.S. at 359. The fund, however, controlled the records. Id.

60. See In re Franklin Nat'l Bank Sec. Litigation, 574 F.2d 662 (2d Cir. 1978), modified, 599 F.2d 1109 (2d Cir. 1979); Blank v. Talley Indus., Inc., 54 F.R.D. 627 (S.D.N.Y. 1972); Bernstein, supra note 33, at 51 .

61. See In re Franklin Nat'l Bank Sec. Litigation, 574 F.2d at 669, 675-76; Blank v. Talley Indus., Inc., 54 F.R.D. at 627.

62. 574 F.2d at $669,675-76$.

63. See 437 U.S. at 349 . Arguably, the cost of notifying meunbers of a class whose shares are held in a street name should be borne by the beneficial owners and their brokers, since it is their 
obtain little benefit from identifymg at their own expense absentee class members, ${ }^{64}$ a nonparty broker would benefit even less. Where a nonparty broker, then, performs the identification task, there is little basis for departing from the ordinary rule articulated in Oppenheimer that the plaintiff inust bear the cost of identification.

\section{OPPENHEIMER AND THE FIDUCIARY DUTY "EXCEPTION"}

The Eisen Court expressly avoided determining whether a corporate defendant might have to bear the cost of notice "where a fiduciary duty pre-existed between the plaintiff and defendant, as im a shareholder derivative suit,"65 or, put another way, where the relationship between the parties is not "truly adversary." 66 The principle justifications for such an approach are that a corporation regularly communicates with its shareholders, so that an additional enclosure in a regular mailing would not be burdensome, and, more importantly, that the plaintiff shareholders will ultimately bear the expense to the corporation. ${ }^{67}$ After Oppenheimer, whatever exception to the normal notice cost rule previously existed based on a fiduciary relationship is a virtual dead letter.

The planitiffs in Oppenheimer were shareholders in an open-ended investinent company, Oppenheimer Fund, Inc. The fund's portfolio was managed by Oppenheimer \& Co., a brokerage firm. The plaintiffs alleged violations of federal securities laws for failure to disclose mate-

convenience that is served by the arrangement. See Bernstein, supra note 33, at 51. The Oppenheimer Court emphasized, however, that "courts inust not stray too far from the principle underlying Eisen $I V$ that the representative plaintiff should bear all costs relating to the sending of notice because it is he who seeks to maintain the suit as a class action." 437 U.S. at 359. Moreover, Rule 23 provides no inechanism for such cost allocation. See In re Franklin Nat'l Bank Sec. Litigation, 574 F.2d 662, $669-70$ (2d Cir. 1978), modiffed, 599 F.2d 1109 (2d Cir. 1979); FED. R. CIv. P. 23(c).

64. See 437 U.S. at 357.

65. 417 U.S. at 178.

66. Id. at 178-79. As an example of a case in which a court had imposed the cost of notice on a defendant on the basis of a fiduciary duty to the plaintiff class, the Eisen Court cited Dolgow v. Anderson, 43 F.R.D. 472 (E.D.N.Y. 1968), rev'd and remanded on other grounds, 438 F.2d 825 (2d Cir. 1971). See 417 U.S. at 178 n.15. The Dolgow court also justified imposing the cost of (c)(2) notice on the defendant on the bases of the defendant's putative interest in binding the plaintiff class under principles of res judicata and of the defendant's ability to bear the expense of notice. 43 F.R.D. at 472. After Eisen, however, these factors were no longer relevant to the notice cost issue. See 417 U.S. at 177-79. Moreover, Eisen III expressly disapproved the Dolgow decision. 479 F.2d at 1012, 1019. Thus, even before Oppenheimer, Dolgow was of questionable precedential value. After Oppenheimer, it is clearly of no precedential value. See text accompanying notes 7989 infra.

67. See Note, Federal Procedure-Class Actions Under 1966 Amendments to Rule 23-Notice and Damage Distribution-Eisen v. Carlisle \& Jacquelin, 479 F.2d 1005 (2d Cir. 1973), 5 U. ToL. L. Rev. 180, 188-89 (1973); 73 Colum. L. Rev. 1641, 1653 n.70 (1973). 
rial information to investors. They brought class actions against the inanager, the brokerage company and its partners, and the officers and directors of the fund and the manager. ${ }^{68}$ The fund was not named as a defendant in the class action. ${ }^{69}$ The shareholders in the fund also brought derivative actions on behalf of the fund, naming as defendants the fund and the class action defendants. ${ }^{70}$ The class and derivative actions were then consolidated. ${ }^{71}$

As an alternative to their identification costs argument, ${ }^{72}$ the shareholders argued that the defendants owed them a fiduciary duty in the inatter of purchases of stock in the fund and that, having breached that duty, the defendants should bear the expense of notice. ${ }^{73}$ The trial court imposed a portion of the notice cost on the defendants without discussing the shareholders' fiduciary duty argument. ${ }^{74}$ On appeal, a panel of the Second Circuit declined to impose the costs on the defendants because the fund was not a party to the class action claims and because the court found no special circumstances, apart from a possible fiduciary relationship, to warrant shifting to the other defendants any of the cost of notice. ${ }^{75}$ The panel decision was reversed on rehearing en banc without mention of the plaintiffs' fiduciary position with the defendants. ${ }^{76}$ In the Supreme Court, the plaintiffs' attempt to impose some notice costs on the defendant was rejected:

A bare allegation of wrongdoing, whether by breach of fiduciary duty or otherwise, is not a fair reason for requiring a defendant to undertake financial burdens and risks to further a plaintiffs case. Nor would it be in the interests of the class of persons to whom a fiduciary duty is owed to require them, through the fiduciary, to help finance every suit by one of their number that alleges a breach of fiduciary duty, without regard to whether the suit has any inerit. ${ }^{77}$

Oppenheimer illustrates the most difficult probleins posed by the Eisen suggestion that the cost of initial notice inight properly be imposed on a corporate defendant in some situations. First, the Eisen

68. 437 U.S. at $340,342-43$.

69. See Sanders v. Levy, 558 F.2d at 640. But see Brief for Respondent at 53, Oppenheimer Fund, Inc. v. Sanders, 437 U.S. 340 (1978).

70. See Sanders v. Levy, 20 Fed. R. Serv. 2d 1218, 1219 (S.D.N.Y. 1975).

71. Id,

72. See text accompanying notes 36-38 supra.

73. Brief for Respondent, supra note 69 , at 54-55.

74. 20 Fed. R. Serv. $2 d$ at 1221.

75. 558 F.2d at $640-41$. Judge Hays dissented in part from the panel decision, arguing that the class action defendants owed the plaintiff shareholders a high level of fiduciary duty under the federal securities laws and thus could be made to bear at least a portion of the cost of notice. $I d$. at $645-46$.

76. Id. at 652 n.2. Judge Hays wrote the en banc opinion overturning the panel.

77. 437 U.S. at 363. 
suggestion presupposes two essential relationships: a fiduciary relationship and a nonadversarial relationship. More importantly, however, those relationships must exist between parties to the class action. In the Oppenheimer class action, the relationship between the fund and the shareholder class was fiduciary and nonadversarial, but the relationship was not between parties. While the class defendants were parties and owed plaimtiffs fiduciary duties, the plaintiffs' claim for dainages against the defendants created an adversarial relationship. ${ }^{78}$

Practically the only situation in which a defendant is nonadversarial and owes a fiduciary duty to the plaintiff is a derivative action. A derivative action, however, is governed by Rule 23.1, ${ }^{79}$ which does not require that initial notice be sent to shareholders. ${ }^{80}$ The plaintiffs im Oppenheimer argued that Eisen could not have intended to limit the fiduciary relationship language to derivative actions for this very reason. ${ }^{81}$ They also sought to overcoine the problem that the fund was not named in the complaint as a defendant by pointing to the named defendants' asserted cross-claims and setoffs against the fund. ${ }^{82}$ Presumably, in this posture the fund could be regarded as a party to the class action claim and yet have interests aligned witl and not truly adversarial to those of the plaintiffs. The Supreme Court did not inention this argument in its decision. ${ }^{83}$ Certainly the assertion by a defendant of a right of setoff or imdemnification against a nonparty can alter the procedural posture of the plaintiff vis-a-vis the third person. ${ }^{84}$ But to the extent that the third person is liable for the claim inade against the defendant, its imterests are clearly adverse to those of the plaintiff. ${ }^{85}$

Even if a defendant owes the plaintiff class a fiduciary duty and is nonadversarial, a second problem remains in distimguishing between

78. See Madonick v. Denison Mines Ltd., 63 F.R.D. 657 (S.D.N.Y. 1974). In Madonick, a corporation was named as a defendant in a class action brought by one of its minority shareholdcrs. The court reasoned that because neither the plamtiff nor the members of the class he sought to represent had a substantial equity interest in the corporation, their interest in obtaining money damages outweighed any concern they unight have about the adverse inpact a damages award would have on the corporation. The court therefore rejected the plaintiffs assertion that the relation of the parties was not "truly adversarial" and that Eisen did not require that plaintiff bear the costs of (c)(2) notice. Id. at 659-60.

79. FED. R. CIV. P. 23.1.

80. 1 Moore's Federal Practice II 1.401 (2d ed. 1969); Kaplan, Continuing Work of the Civil Committee, 1966 Amendments of the Federal Rules of Civil Procedure (I), 81 HARv. L. REv. 356, 387 n.118 (1967).

81. Brief for Respondent, supra note 69, at 55.

82. Id. at 57-58. See 437 U.S. at 344 n.4.

83. See 437 U.S. at 363-64.

84. See FED. R. Civ. P. 14 (impleader).

85. Rule 14(a) provides that "[t]he third-party defendant may assert against the plaintiff any defenses which the third-party plaintiff has to the plaintiff's clain." 
meritorious and unmeritorious claims that the fiduciary duty was breached. ${ }^{86}$ The Eisen Court concluded that Rule 23 did not ordinarily authorize a preliminary inquiry into the merits of a proposed class action as a means of allocating notice costs: such a "procedure is directly contrary to the command of subdivision (c)(1) that the court determine whether a suit denommated a class action inay be maintamed as such '[a]s soon as practicable after the commenceinent of [the] action.' "87 Although the Court left open the allocation question in cases involving fiduciary duties and nonadversarial relationships, ${ }^{88}$ Rule 23 affords no guidance whatsoever for allocating notice costs. Any attempt to evaluate by preliminary inquiry the merits of a proposed class action raises the same probleins under the notice provisions of Rule 23, regardless of the basis for the suit. ${ }^{89}$

\section{Advancement and Solicitation by Counsel of Notice Costs}

The potentially high cost to (b)(3) plaintiffs of (c)(2) notice has focused attention on the fee arrangements between would-be class representatives and their attorneys and on the financial resources of $(b)(3)$ plamtiffs. Some commentators have suggested, and some plaintiffs have agreed, that attorneys of class representatives can assist $\mathrm{m}$ easing the plaimtiffs' notice costs burden by advancing the costs of the hitigation and by soliciting funds from absent class members. ${ }^{90}$ Under the ABA Code of Professional Responsibility, an attorney can advance the plaintiff, or solicit from class members, the costs of the class action, but the attorney cannot assume those costs. ${ }^{91}$

86. See 437 U.S. at 363.

87. 417 U.S. at 178.

88. Id. at 178 n.15.

89. In Popkin v. Wheelabrator-Frye, Inc., 20 Fed. R. Serv. 2d 125, 129-30 (S.D.N.Y. 1975), the court reasoned that

[a]s a result [of Eisen] any principle on the basis of which costs could be allocated would, of necessity, be an essentially inflexible one. Thus, if it were to be decided that in suits where the defendants owed a fiduciary duty to the plaintiffs, defendants should bear the cost of notice, this principle would have to be applied to all suits where such a preexisting fiduciary duty existed regardless of the size of the class or the strength or weakness of the case.

90. See, e.g., Sayre v. Abrahain Lincoln Fed. Sav. \& Loan Ass'n, 65 F.R.D. 379 (E.D. Pa. 1974), amended, 69 F.R.D. 117 (E.D. Pa. 1975); Cohen, supra note 25, at 1.

91. The Code of Professional Responsibility provides that an attorney may advance the costs of litigation only if the client remains hable ultimately for the expenses. ABA CODE OF ProfesSIONAL RESPONSIBILITY D.R. 5-103(B). Notice costs under Rule 23(c)(2) fall within the meaning of costs under D.R. 5-103(B). See Halverson v. Convenient Food Mart, Inc., 458 F.2d 927, 931 n.7 (7th Cir. 1972); P.D.Q., Inc. v. Nissan Motor Corp., 61 F.R.D. 372 (S.D. Fla. 1973). If a client seeking to represent a class of plaintiffs does not agree to assume ultimate liability for the extra costs of the class litigation, the suit must be brought as an individual one or the lawyer must 
Defendants against class actions, however, frequently atteinpt to obtain discovery into the class representatives' finances and fee arrangements with counsel, arguing that advanceinent or solicitation of costs raises questions about the adequacy of the plaintiffs representation of the class. ${ }^{92}$ It is asserted that in order to represent the class fairly and adequately the representatives must be financially able to bear the notice and other costs of litigation. ${ }^{93}$ Where the class representatives are unable or unwilling to bear these costs, their attorneys, by proceeding with the action, would be violating the Code of Professional Responsibility. ${ }^{94}$ If the representatives' counsel are guilty of ethics violations, the argument goes, then the representatives cannot adequately represent the class and class action status should be denied. ${ }^{95}$ Nained plaintiffs counter that their ability to finance the costs of litigation is no more relevant in class actions than in nornal lawsuits. $^{96}$

To the extent that Oppenheimer limits the use of other devices for easing the cost burden of (c)(2) notice, atteinpts to utilize the advantages of solicitation and advanceinent will becoine more common. Two questions, then, are posed by efforts to obtain discovery into the personal finances and attorneys' fee arrangements of (b)(3) plaintiffs: whether the discovery rules or the provisions of Rule 23 provide the proper model for inquiry into the plaintiff's finances and fee arrangements; and what is the proper scope of such inquiries. As will be shown, ${ }^{97}$ the discovery rules provide the proper model, and a limited inquiry into the plaimtiff's finances can protect the interests of the class and of the parties to the action.

withdraw. ABA Comm. on Professional Ethics, Opinions, No. 1283 (1973). Moreover, where the client does not agree to assume the costs, the attorney may not attempt to obtain settlement by threatening a class action. Id. See also id. No. 1361 (1976).

A lawyer may not recommend or request another lawyer to recommend his employment as a private practitioner to a nonlawyer who has not sought his advice regarding the employment of a lawyer. D.R. 2-103. If the success of a chient in class action litigation is dependent on joinder of otliers, "a lawyer may accept, but shall not seek, employment froin those contacted for the purpose of obtaining their joinder." D.R. 2-104(A)(5). It is ethically proper for an attorney to solicit funds from class members to be used to help defray expenses of mailing notice to all class members. ABA Comm. on Professional Ethics, Opinions, No. 1326 (1975).

92. See, e.g., Stavrides v. Mellon Nat'l Bank \& Trust Co., 60 F.R.D. 634 (W.D. Pa. 1973). One prerequisite to maintaining any class action is that "the representative parties will fairly and adequately protect the interests of the class." FED. R. CIV. P. 23(a)(4).

93. See, e.g., Guse v. J.C. Penney Co., 409 F. Supp. 28 (E.D. Wis. 1976), rev'd on other grounds, 578 F.2d 6 (7th Cir. 1977).

94. Id. See note 91 supra.

95. See, e.g., Elster v. Alexander, 74 F.R.D. 503 (N.D. Ga. 1976).

96. See, e.g., Sanderson v. Winner, 507 F.2d 477 (I0th Cir. 1974), cert. denied, 421 U.S. 914 (1975).

97. See notes $98,114-15$ infra and text accompanying notes 98-120 infra. 


\section{A. The Proper Model for Inquiry.}

The Oppenheimer decision, while limited on its facts to the relationship of the discovery rules to the notice requirement of Rule 23(c)(2), nonetheless provides soine insights into the relationship between the discovery rules and issues arising under the broader requirements of Rule $23 .{ }^{98}$ The Court noted that Rule 23 "deals coinprehensively with class actions," rule gives the trial court broad discretion in conducting the hitigation. ${ }^{100}$ Just as a district court must routinely answer questions relatimg to the form and manner of sending class notice in (b)(3) actions, one arguinent upon which the Oppenheimer Court based its decision, ${ }^{101}$ so inust the district court address the question of the adequacy of representation in purported class actions. Carrying this analysis one step further, a district court could handle questions concerning the adequacy of representation, including the plaintiff's finances and his fee arrangements with counsel, under Rule 23(d), drawing on the discovery rules by analogy for guidance.

On the other hand, the Oppenheimer Court distinguished information relating simply to the sending of notice and information that "may bear on some issue which the District Court must decide."102 Clearly, the ability of the plaimtiff to represent fairly and adequately the interests of the class is an issue for the court to decide in every proposed class action. ${ }^{103}$ Moreover, adequacy of representation is only one of the prerequisites to a class action, ${ }^{104}$ and courts generally allow discov-

98. At least one district court has concluded that the defendant's questions regarding the financial arrangements between the would-be class representative and his counsel and the plaintiff's ability to satisfy a judginent for costs were outside the scope of the discovery rules because the information sought was not relevant to the subject matter of the action. See Bogosian v. Gulf Oil Corp., 337 F. Supp. 1228, 1230 (E.D. Pa. 1971). Apparently, however, the defendants in Bogosian made no argument that the plaintiff's finances and fee arrangements related to his ability to represent the class fairly and adequately. Id. Other district courts, however, have reached the opposite conclusion. See, e.g., Sayre v. Abraham Lincoln Fed. Sav. \& Loan Ass'n, 65 F.R.D. 379 (E.D. Pa. 1974), amended, 69 F.R.D. 117 (E.D. Pa. 1975); Stavrides v. Mellon Nat'l Bank \& Trust Co., 60 F.R.D 634 (W.D. Pa. 1973); $c f$. Sanderson v. Winner, 507 F.2d 477, 480 (10th Cir. 1974), cert. denied, 421 U.S. 914 (1975) (court assumed, without discussion, that the discovery rules provided the proper model for inquiring into the finances and fee arrangements of class action plaintiffs).

99. 437 U.S. at 354.

100. Id.

101. Id. at 355 n.23.

102. Id. at 353 n.18. The problem in Oppenheimer was that, in the Court's view, the issue of whether the required notice had properly been sent would not arise until the absentee class inembers had been identified and notice had been sent. Id. at $354 \&$ n. 19.

103. See FED. R. CIV. P. 23(a)(4).

104. FED. R. CIV. P. 23(a). 
ery regarding the appropriateness of a class action. ${ }^{105}$ While a plaintiff's ability to finance hitigation is not an issue in an ordinary lawsuit, ${ }^{106}$ neither is adequacy of representation. Certainly the issue of finances and fee arrangements is of solne relevance in determining the plaintiff's ability to represent the class adequately, particularly where large notice costs may be involved. ${ }^{107}$ Representative plaintiffs' concerns about intrusive discovery into finances and fee arrangements can be accommodated by a careful delineation of the scope of inquiry.

\section{B. The Scope of the Inquiry.}

The view that arrangements for advances and solicitation of litigation expenses are vehicles for widespread abuse of (b)(3) has some justification. ${ }^{108}$ But for the class action plaintiff of modest means faced with substantial notice and other costs, the value of counsel's advancement or solicitation from absent class members of funds to defray litigation expenses is clear: without such arrangements, those litigants could not pursue their clains. ${ }^{109}$ Wide-ranging discovery into the personal finances and agreements with counsel of plaintiffs who have made arrangeinents for advances or solicitation might discourage the litigation of meritorious claims. ${ }^{110}$ Rule 69(a), ${ }^{111}$ which authorizes discovery into the assets of a judgment debtor, suggests that a litigant's assets are not a proper subject of discovery prior to judgment. ${ }^{112}$ Moreover, alleged ethical problems in class actions are normally the subject of inquiry in a separate proceeding froin that of the class action certification hearing; inisconduct on the part of an attorney should not prejudice the rights of the client. ${ }^{113}$

105. See 7A C. WRight \& A. MiLler, supra note 25 , at $\S 1785$, at 131 \& n.57 (Supp. 1978), and cases cited therein.

106. See Sanderson v. Winner, 507 F.2d 477, 479 (10th Cir. 1974), cert. denied, 421 U.S. 914

(1975); Bogosian v. Gulf Oil Corp., 337 F. Supp. 1228, 1230 (E.D. Pa. 197I).

107. See Sanderson v. Winner, 507 F.2d at 480.

108. See Rode v. Emery Air Freight Corp., 76 F.R.D. 229 (W.D. Pa. 1977); Andrews, The Class Action Bar: It's All Cat and Mouse, 4 JuR1s Doctor 18, 19 (1974).

109. See Sayre v. Abraham Lincoln Fed. Sav. \& Loan Ass'n, 65 F.R.D. 379 (E.D. Pa. 1974), amended, 69 F.R.D. 117 (E.D. Pa. 1975); ABA CoDE of Professional Responsibility E.C. 5-8.

110. See Bernstein, supra note 33, at 50 .

111. FED. R. CIV. P. 69(a) reads in pertinent part:

In aid of the judgment or execution, the judgment creditor or his successor in interest when that interest appears of record, may obtain discovery from any person, including the judgment debtor, in the manner provided in these rnles or in the manner provided by the practice of the state in which the district court is held.

112. Id. See Federal Sav. \& Loan Ins. Corp. v. Krueger, 55 F.R.D. 512 (N.D. Ill. 1972); Gangemi v. Moor, 268 F. Supp. 19 (D. Del. 1967). But of. Ralston v. Volkswagenwerk, A.G., 61 F.R.D. 427,434 (W.D. Mo. 1973) (financial resources of plaintiff are relevant to question of adequacy of representation).

113. See 7 C. Wright \& A. Miller, supra note 25, at § 1766, at 166 \& n.81.1 (Supp. 1978) 
To accommodate the need of class representatives for financial assistance and, at the same time, to limit the potential for abuse of the (b)(3) class action through unethical conduct by counsel, the party opposing class action certification could be limited imitially to an mquiry into the plaimtiff's understanding of his obligation to pay notice and other costs, and of his arrangements with counsel vis-a-vis those costs. If the plaintiff understood the obligation and arrangements, no additional inquiry into his finances and arrangements with counsel would be permitted unless judgment were rendered agamst him. ${ }^{114}$ Several courts, lowever, have disregarded the benefits of advances and solicitation of litigation expenses, einpliasizmg instead the potential for abuse, and have permitted wide-ranging discovery into the financial status of the plaintiff. ${ }^{115}$

Another argument that has been advanced to support discovery of the plaintiff's finances is that under some federal statutes ${ }^{116}$ a defendant who prevails on the merits might be entitled to recover as costs attorneys' fees from the plaintiff; it is asserted that this protection would be ineaningless if the finances of the representative plaintiff cannot be ascertained at the outset of the litigation. ${ }^{117}$ Courts, however, will usually award a prevailing defendant attorneys' fees only where the plaimtiff brouglit a frivolous or bad faith claim. ${ }^{118}$ As a practical matter, this determination can be made only after a resolution of the case on the merits. If the merits are resolved before class certification, as where the defendant prevails agamst the plaintiff on summary judgment, then the

(discipline attorney, send remedial notice to class, but do not dismiss action), and cases cited therein.

114. See Sayre v. Abraham Lincoln Fed. Sav. \& Loan Ass'n, 65 F.R.D. 379, 385-86 (E.D. Pa. 1974), amended, 69 F.R.D. 117 (E.D. Pa. 1975); cf. Lim v. Citizens Sav. \& Loan Ass'n, 430 F. Supp. 802, 812-13 (N.D. Cal. 1976) (refusal by plaintiff to answer defendant's questions about fee arrangements with counsel could be grounds for denial of class certification); see also Sanderson v. Winner, 587 F.2d 477, 480 (10th Cir. 1974), cert. denied, 421 U.S. 914 (1975).

115. See, e.g., Rode v. Emery Air Freight Corp., 76 F.R.D. 229, 230 (W.D. Pa. 1977) (plaintiff's arrangement with her attorney for advancement of costs raised the possibility of abusing Rule 23 by "the substitution of plaintiff's attorney for the representative plaintiff or the plaintiff class as the real party in interest"); Elster v. Alexander, 74 F.R.D. 503 (N.D. Ga. 1976) (court ordered the plaintiff, whose individual stake was $\$ 800$, to answer numerous interrogatories respecting his financial ability to maintain the action, his financial arrangements with counsel, his personal litigating background, and his experience in purchasing and selling securities). See also Stavrides v. Mellon Nat'l Bank \& Trnst Co., 60 F.R.D. 634, 637 n.6 (W.D. Pa. 1973).

116. E.g., 42 U.S.C. $\S \S 173 /(\mathrm{e}), 1988,2000 \mathrm{e}-5(\mathrm{c})$ (1976).

117. See Rode v. Emery Air Freight Corp., 76 F.R.D. 229, 231-32 (W.D. Pa. 1977).

118. See, e.g., Goff v. Texas Instruments, Inc., 429 F. Supp. 973, 975 (N.D. Tex. 1977); Hughes v. Repko, 429 F. Supp. 928, 931 (W.D. Pa. 1977), rev'd in part on other grounds, 578 F.2d 483 (3d Cir. 1978); Lee v. Chesapeake \& Ohio Ry., 389 F. Supp. 84, 85 (D. Md. 1975); Paddison v. Fidehity Bank, 60 F.R.D. 695, 699 (E.D. Pa. 1973); Richardson v. Hotel Corp. of America, 332 F. Supp. 519, 521-22 (E.D. La. 1971), affd, 468 F.2d 951 (5th Cir. 1972). 
question of whether the defendant is entitled to attorneys' fees can be answered without reaching questions about adequate representation. Apart from summary judgment situations, however, Eisen makes it clear that courts cannot inquire into the merits of a suit in order to determine whether it may be maintamed as a class action. ${ }^{19}$ Because the question of a plaintiff's liability for the defendant's attorneys' fees is intertwimed with the merits of the suit, it would be improper to consider a plaintiff's ability to pay such fees im determining that plaintiff's ability to represent the class adequately. The proper time for discovery of the plaintiff's assets would be after judgment has been awarded for the defendant. ${ }^{120}$

The better approach to prejudgment discovery of a plaimtiff's assets and arrangements with counsel is to allow only a narrow imquiry to insure that the plaintiff properly understands his responsibility for the notice and other costs of the litigation. However, the possibility that the court im which the action is filed will allow widc-ranging inquiry suggests that the sometimes high cost of (c)(2) notice compounds questions about adequacy of representation in (b) (3) suits. If abuses of subdivision (b)(3) procedures do exist in the form of mamtenance and other unetlical conduct by attorneys, that abuse imight indicate that the burden of (c)(2) notice is at times prohibitive for would-be class representatives.

\section{Test Case Procedures}

While Oppenheimer did not involve questions about the use of a test case procedure to mimimize notice costs, its holding that identification of absent class members is part of the plamtiff's notice obligation and that preexisting fiduciary relationships will not support imposing on defendants any of the cost of notice increases the relative significance of other means of minimizing notice costs. The test case procedures suggested by Justice Douglas in his Eisen opinion ${ }^{121}$ and by the Third Circuit in Katz v. Carte Blanche Corp. ${ }^{122}$ however, are of little, if any, value to (b)(3) plaintiffs seeking to minimize or avoid the initial cost of (c)(2) notice. Both procedures are legally unsound and at best would provide plaintiffs with relief from notice in very limited circumstances.

119. 417 U.S. at 177.

120. See FeD. R. CIv. P. 69(a). See notes 111-12 supra and accompanying text.

121. 417 U.S. at 179-86 (Douglas, J., dissenting in part).

122. 496 F.2d 747 (3d Cir.), cert. denied, 419 U.S. 885 (1974). For an analysis of the Carte Blanche decision apart from its relevance to the notice cost problem, see 88 HARV. L. REv. 825 (1975). 


\section{A. Justice Douglas' Test Case Procedures.}

Although the Eisen majority dismissed the plamtiff's class action as originally defined because of his unwillingness to pay the cost of notice, Justice Powell emphasized that the dismissal was "without prejudice to any efforts petitioner may make to redefine his class under Rule 23(c)(4) . . . ."123 Justice Douglas, in his separate opinion dissenting in part from the majority decision, argued that instead of disunissing the plaintiff's action, the district court could, under subdivision (c)(4), define the subclasses "without amendment of the complaimt as filed." 124 One subclass could then be treated as a test case, with the other subclasses held in abeyance. ${ }^{125}$ This procedure would, in effect, change a nonmanageable class imto several manageable subclasses, in an effort to lessen the cost to the plaimtiff of the initial notice required by subdivision (c)(2). ${ }^{126}$

The use of a subclass-test-case procedural device to lessen a (b)(3) plaintiff's notice cost burden poses a number of problems. First, as Justice Douglas recognized, it is not clear what inipact an adjudication of the claims of one subclass would have on the clainis of the members of the larger class who are not parties. ${ }^{127}$

If the subclass lost, it is argued that other investors not members of that subclass could not be precluded from prosecuting successful suits of their own, since they had never had their day in court or necessarily even been apprised of the subclass' action .... If the subclass won, strict apphication of the doctrine of inutuality of estoppel would limit the usefulness of that subclass victory in suits brought by investors not members of that subclass. ${ }^{128}$

Conceivably, then, the outcome of such a test case would bind only the members of that subclass, subject to opting out, and the question of defendant's hability or wrongdoing would remain open as to the remainder of the class, all because the first plaintiff who undertook to represent the class was unwilling or unable to bear the cost of (c)(2) notice to the entire class. Such a procedure would not serve the underlying policies of subdivision (b)(3) in achieving "econornies of time, effort and expense," 129 nor would it promote uniformity of decisions as

123. 417 U.S. at 179 n.16. See note 29 supra.

124. 417 U.S. at 183.

125. Id. at 179-80 (citing Eisen III, 479 F.2d 1005, 1023 (Oakes, J., dissenting froun denial of rehearing en banc)).

126. See 417 U.S. at 181 .

127. Id. at 181-82. Justice Douglas was also concerned that the statute of limitations unight run against meinbers of the larger class that would not be ineinbers of the plaintiffs amended subclass. Id. at 181 .

128. Id. at 182 n.3.

129. Advisory Comm. Note 102. 
to persons similarly situated. ${ }^{130}$ In addition, neither the language of subdivisions (b)(3) and (c)(4) nor the history behind Rule 23 provides any basis for a subclass test case procedure. ${ }^{131}$ In Eisen, the Supreme Court rejected for this same reason the use of the preliminary minihearing device, ${ }^{132}$ indicating the necessity for at least a general adherence to the mechanics of Rule 23 , even at the risk of imposing a substantial notice cost on a (b)(3) plaimtiff.

Another question posed by the subclass test case procedure is whether a plaintiff's unwillingness or inability to bear notice costs amounts to nonmanageability. Put another way, the question arises whether a court could divide a class into subclasses simply to ease the burden of notice costs on the plaintiff. Justice Douglas looked at manageability in terms of the plaintiff's willingness or financial ability to satisfy the notice requirements of (c)(2). ${ }^{133}$ The inajority in Eisen III, however, regarded the case as unmanageable as a class action because of the inechanical and adinimistrative problems involved in notifying the six inillion ineinbers of the class and in fashioning a procedure for processing their individual claims in the event that the plaintiff prevailed. ${ }^{134}$ This suggests that manageability is a function of fairness to the members of the class, not of a plaintiff's interest in mimimizing the cost of notice. ${ }^{135}$ Moreover, the Advisory Coininittee's Note on subdivision (c)(4)(B) speaks of "subclasses divergent im interest," 136 and not subclasses created to deal with problems of manageabihty. Subdivision (c)(4), then, does not support dividing a class into subclasses sinply because the plaimtiff wants to lessen the cost of (c)(2) notice, especially if the division is part of a test case procedure.

130. See id. 102-03.

131. The Advisory Committee regarded the test case procedure as an alternative to a (b)(3) class action. See id. 103.

132. 417 U.S. at 177-78.

133. $I d$. at 180 n.l.

134. 479 F.2d at 1016-17. The Supreme Court left this finding undisturbed. 417 U.S. at 169 .

135. In Oppenheimer, the Court cited Justice Douglas' Eisen opinion to support the statement that "it [is not] improper for the court to consider the potential impact that rulings on [the composition of a proper class and how notice should be sent] . . may have on the expense that the representative plaintiff must bear in order to send the notice." 437 U.S. at 360 . This dictum, however, was in the context of the Court's determination that the defendants could not be made to bear any of the cost of notice simply because they opposed the plaintiffs' attempt to reduce that cost by redefining the class. See id. at 359-60. Moreover, the district court in Oppenheimer rejected the plaintiffs' proposed redefinition as "arbitrary" because the imterests of the original class members who were to be excluded from the redefined class were the same as the interests of those members not excluded. 20 Fed. R. Serv. $2 d$ at 1221.

136. Advisory Comm. Note 106. 


\section{B. The Carte Blanche Test Case Procedure.}

In Katz v. Carte Blanche Corp. ${ }^{137}$ the Third Circuit en banc postponed the class action determination required by subdivision (c)(1) until a judginent had been rendered establishing whether the defendant had violated the Truth in Lending Act $^{138}$ as plaintiff alleged. The trial court had certified the plaintiff's claiins as a (b)(3) class action and ordered the plaintiff to send (c)(2) notice over Carte Blanche's objections that almost all of the ineinbers of the class were its account debtors, and that there was a substantial likelihood that upon receipt of the notice they would witlihold payinents, with catastrophic effects to Carte Blanche. ${ }^{139}$ Carte Blanche therefore sought to postpone class certification until after a determination of liability. The circuit court adopted a test case procedure by which the defendant's hability would be determined in an individual action. Judginent against the plaintiff would not bind the class, while judgment against the defendant would bind the defendant as to all class ineinbers. ${ }^{140}$ If the defendant lost on the issue of hability, the class would be certified and notice sent to the class members, advising thein of the judginent establishing a violation. ${ }^{141}$ One benefit from the procedure, the court noted, would be to save plaintiff the substantial expense of initial netice to the class if the defendant prevailed; if defendant lost as to liability, then the cost of notice could be imposed on the defendant. ${ }^{142}$

The Carte Blanche court recogmized that this procedure bore a strong resemblance to the spurious class action category of Rule 23 before the 1966 ainendments, which liad permitted one-way intervention by class meinbers after a determination of defendant's liability in a nonclass or individual action. ${ }^{143}$ The 1966 annendments purported to eliminate such one-way intervention and reflect a policy of inutual estoppel. ${ }^{144}$ The Carte Blanche court reasoned, however, that one-way intervention served all the policies of (b)(3), with the exception of the defendant's interest in inutual estoppel, and since Carte Blanche sought "not to have conferred upon it what it perceives to be the dubious bene-

137. 496 F.2d 747 (3d Cir.), cert. denied, 419 U.S. 885 (1974).

138. 15 U.S.C. $\S \S 1601-1667$ (e) (1976).

139. 496 F.2d at 757.

140. Id. at 758-59.

141. Id. at $760-61$.

142. Id. at 761 .

143. Id. at 759. Under the old rule, the practice had developed that class members could "intervene after a decision on the inerits favorable to their interests, in order to secure the benefits of the decision for theinselves, although they would presumably be unaffected by an uufavorable decision." Advisory Comm. Note 105 (emphasis in original) and cases cited therein.

144. Advisory Comm. Note 106. 
fit of mutual estoppel," 145 the test case procedure was a proper alternative to certifymg the plaintiff class under subdivision (b)(3) of Rule 23. The court also reasoned that the scope of the doctrine of inutuahty of estoppel had been narrowed since the 1966 amendments to Rule 23. ${ }^{146}$

The reasoning of the Carte Blanche majority is unsound in two significant respects. First, although the scope of the inutuahty of estoppel doctrine may have been narrowed, the leading Supreme Court decision on the subject is at best a very limited holding. ${ }^{147}$ In addition, to the extent that the 1966 amendments to subdivision (b)(3) refiect a policy of mutual estoppel, the case law certainly does not support a rejection of mutual estoppel in (b)(3) class actions. ${ }^{148}$

Second, the test case procedure proposed by the Carte Blanche court runs counter to the requireinent in subdivision (c)(1) that "[a]s soon as practicable after the commencement of an action brought as a class action, the court shall determine by order whether it is to be so maintamed." 149 If, as the Supreme Court reasoned in Eisen, a preliminary mini-hearing is imconsistent with the mandate of subdivision (c)(1), ${ }^{\text {iso }}$ then, similarly, (c)(1) prevents the use of a test case on the issue of liability prior to a determination of the class. ${ }^{151}$

For the class action plaintiff who might look to the Carte Blanche test case procedure as a means of avoiding the cost of the notice required by subdivision (c)(2), yet another problein exists. In Bogus $v$.

145. 496 F.2d at 760 .

146. Id. The court relied principally on Blonder-Tongue Laboratories, Inc. v. University of Ill. Foundation, 402 U.S. 313 (1971).

147. See Blonder-Tongue Laboratories, Inc. v. University of Ill. Foundation, 402 U.S. 313 (1971). The Blonder-Tongue Court emphasized that its decision depended "on the considerations weighing for and against permitting a patent holder to sue on his patent after it has once been held invalid following opportunity for full and fair trial." Id. at 330. The Court's analysis focused on the economic costs of adherence to mutuality of estoppel and "the nature of the burden, if any, that permitting patentees to relitigate patents once held invahid imposes on the federal courts." Id. The dissenters in Carte Blanche criticized the majority for failing to adhere to the Blonder-Tongue analysis. 496 F.2d at 766-67 (Seitz, C.J., dissenting); id. at 770-71 (Aldisert, J., dissenting).

148. Cf. 88 HARV. L. REv. 825,829 n.27 ("Rule 23 does not, of course, restrict the development by federal courts of the law of collateral estoppel in nonclass suits").

149. FED. R. Civ. P. 23(c)(1).

150. 417 U.S. at 178 .

151. See Jiminez v. Weinberger, 523 F.2d 689, 698 n.17 (7th Cir. 1975), cert. denied, 427 U.S. 912 (1976); Peritz v. Liberty Loan Corp., 523 F.2d 349, 353 (7th Cir. 1975); Fitzgerald v. Northeastern Hosp., 418 F. Supp. 1041 (E.D. Pa. 1976); ff. Advisory Comm. Note 106 ("Under proposed subdivision (c)(3) . . . the action will have been early determined to be a class or nonclass action, and in the former case the judgment, whether or not favorable, will include the class"). Although Justice Douglas' subclass test case procedure would vary from the Carte Blanche test case by litigating the liability issue in a subclass action, it is arguable that his proposal contemplated a recertification of the entire class following a judgment in the subclass action. See 417 U.S. at 18081. Suclı a procedure would also run afoul of subdivision (c)(l). 
American Speech \& Hearing Association, ${ }^{152}$ the Third Circuit, citing its Carte Blanche decision, concluded that a test case procedure would be superior to a normal (b)(3) class action where, inter alia, the plaintiff had "Inanifested [her] intention to continue her hitigation even in the face of a denial of class certification . . .."153 This conclusion is consistent with the purpose behind subdivision (b)(3) of providing a class of damaged persons who would not otherwise litigate their claims individually with a procedural device for collectively pursuing those claims. ${ }^{154}$ However, for the potential class representative whose individual claim is so small that it neither warrants an individual action nor the paynient of the cost of notice to the entire class, the Bogus court's language strongly suggests that the Carte Blanche test case procedure would be an mappropriate alternative to the normal rule requiring certification of the class before an adjudication of the defendant's liability. ${ }^{155}$ Whatever benefits the Carte Blanche test case procedure might create for (b)(3) plaintiffs faced with the substantial expense of notice to the class, then, would be unavailable to the very plaintiffs who most needed those benefits.

In any event, the consent of the defendant is probably the most important precondition to the test case procedure developed in Carte Blanche. Indeed, the majority there noted that "[i] $\mathrm{f}$ a class action defendant insists upon early class action determination and notice, he is, under the rule, entitled to it." 156 Subsequent decisions have consistently limited the Carte Blanche test case procedure to situations in which the defendant consents to the procedure or waives his right to early class action determination and notice. ${ }^{157}$ As a practical matter, it seems unlikely that defendants against class actions would consent to a test case on liability before certification of the class, simply to ease the plaintiff's notice cost burden.

\section{OIAJ PROPOSAL}

A recent proposal by the Office for Improvements in the Administration of Justice of the Department of Justice (OIAJ), ${ }^{158}$ later modified

152. 582 F.2d 277 (3d Cir. 1978).

153. Id. at 290.

154. See Advisory Comm. Note 104.

155. 582 F.2d at 290.

156. 496 F.2d at 762 .

157. See, e.g., Peritz v. Liberty Loan Corp., 523 F.2d 349, 353-54 (7th Cir. 1975); Fitzgerald v. Northeastern Hosp., 418 F. Supp. 1041 (E.D. Pa. 1976); Link v. Mercedes-Benz of N. America, Inc., [1975-2] Trade Cas. ๆ 60,534 (E.D. Pa.), remanded, 550 F.2d 860 (3d Cir.), cert. denied, 431 U.S. 933 (1977).

158. OfFice for IMPRovements in the Administration of Justice, supra note 6. 
and introduced in the Senate, ${ }^{159}$ raises the possibility of radical clianges in class action procedure. ${ }^{160}$ The OIAJ proposal as inodified deals coinprehensively witl the problens raised by the (b)(3) class action, and thus affects the problem of notice.

Briefly, the proposal is intended to repeal subdivision (b)(3) and replace it with two statutory procedures. ${ }^{161}$ The first, a public action procedure, is available where at least 200 persons have each sustained an injury not exceeding $\$ 300$, with aggregate dannages of $\$ 60,000$ or more, and a coininon question of law or fact exists as to each person. ${ }^{162}$ A public action could be brought in federal district court either by the United States or on behalf of the United States by an injured person. ${ }^{163}$ The United States Attorney General would have the option of assuming control of the action, assigning the action to a state attorney general, pernitting an individual who brought an action to proceed on behalf of the United States, or recominending that the action not be allowed to proceed as a public action. ${ }^{164}$

To protect defendants against strike suits and over-discovery, a prcliminary liearing would be held soon after filing the action to evaluate whether the suit should be allowed to continue as a public action. ${ }^{165}$ If recovery were eventually awarded the United States, a dainage fund would be created and coinpensation to injured persons would be handled by the Administrative Office of the United States Courts. ${ }^{166}$ The measure of dannages would be either the ineasure of the benefit to the defendant of its violation of federal law or the coinbined value of damages to individual persons not in excess of $\$ 300$ each. ${ }^{167}$

The proposal assuines that adequate representation can be assured by ineans other than individual notice, including supervision by the United States, inquiry by the court into the coinpetency of counsel, and regulation of attorneys' fees, including incentives for successful ac-

159. S. 3475. The Senate bill contains several material changes of the original OIAJ proposal; the discussion here focuses on the S. 3475 version. Senator DeConcini, co-sponsor of the bill with Senator Kennedy, stated upon introducing the bill that consideration of the proposal would continue into the 96th Congress. 124 CoNG. Rec. S14,501 (daily ed. Aug. 25, 1978) (remarks of Sen. DeConcini).

160. See Meador, Proposed Revision of Class Damages Procedures, 65 A.B.A.J. 48 (1979).

161. 124 Cong. Rec. S14,501 (daily ed. Aug. 25, 1978) (remarks of Sen. DeConcini).

162. S. $3475 \S 3001$.

163. Id.

164. Id. $\S 3002$.

165. Id. $\$ 3001$.

166. Id. $\$ 3007$.

167. Id. $\S 3006$. 
tions. ${ }^{168}$ If recovery is awarded against a defendant, the court could provide that notice to injured persons be made through publication and other suitable means. ${ }^{169}$ The cost of such notice would be borne by the recovery fund. ${ }^{170}$

The second procedure proposed, a class compensatory procedure, is available where at least forty persons have each suffered injury exceeding $\$ 300$, and a common question of law or fact exists as to each person. ${ }^{171}$ The representative party and counsel inust also adequately represent the class. ${ }^{172}$ A preliminary hearing similar to that required in a public action is also part of the class compensatory procedure. ${ }^{173}$ To ensure adequate representation of absentee interests, the court inust order notice to the class, but individual notice is discretionary, not mandatory. ${ }^{174}$ The commentary to the Senate proposal suggests that the greater the individual amounts in controversy, the more willing a court should be to require mdividual notice. ${ }^{175}$

The OIAJ proposal as modified clearly addresses many of the shortcommgs of subdivisions (b)(3) and (c)(2) vis-a-vis preliminary notice to absentee class inembers. The public action procedure eliminates preliminary notice altogether. ${ }^{176}$ Both the public action and class compensatory procedures adopt the widely held view that preliminary individual notice is not the only way to ensure adequate protection and representation of absentee class menbers. ${ }^{177}$ Consistent with this approach, any due process shortcommgs raised under (b)(3) and (c)(2) by not sending individual notice can be attributed to the lack of other protections under those subdivisions, protections that exist in the proposed public action and class coinpensatory procedures. The flexible preliminary notice provisions of the class compensatory procedure also reflect the view that individual notice is more effective in soine circumstances than in others. ${ }^{178}$ Moreover, the suggestion that preliminary individual notice of the opt-out privilege becomes inore important as individual stakes increase is consistent with the approach that plamtiffs with small

168. See OFFICE FOR IMPROVEMENTS IN THE ADMINISTRATION OF JuSTICE, supra note 6, at 38; 124 CONG. REC. S14,505 (daily ed. Aug. 25, 1978) (bill commentary to S. 3475).

169. S. $3475 \S 3007$.

170. Id

171. Id. $\$ 3011$.

172. $I d$.

173. Id $\$ 3013$.

174. Id

175. See 124 Cong. Rec. S14,506 (daily ed. Aug. 25, 1978).

176. See id. S14,504.

177. See, e.g., Comment, The Importance of Being Adequate: Due Process Requirements in Class Actions Under Federal Rule 23, 123 U. PA. L. REV. 1217 (1975).

178. Dam, supra note 21; Comment, supra note 177. 
individual stakes should not be burdened with extremely high preliminary notice costs.

While the OIAJ proposal as modified expressly provides the court with the discretion, when considering the adequacy of representation, to inquire into agreements between counsel and client regarding attorneys' fees and the conduct of the litigation, ${ }^{179}$ the proposal does not suggest any guidelines for the scope of such inquiry. Moreover, the proposal does not address the relevance of the plamtiff's ability to bear the costs of litigation. Under the public action procedure, where a private party inaintains the action in the name of the United States, it might be argued that because the party bringing the action does not face any prelininary notice costs, his personal finances are even less relevant to the question of adequate representation than under subdivision (b)(3). Still, preliminary notice might be required in a class coinpensatory procedure. ${ }^{180}$ One method of dealing with the personal finances problem would be expressly to allow a defendant during discovery to inquire initially only into the plaintiff's understanding of his liability for costs of litigation and the nature of his fee arrangement with counsel. If the plaintiff did not understand this obligation or his fee arrangement with counsel, further inquiry should be permitted. If the plaintiff refused to answer the question, the case should not be allowed to proceed. ${ }^{181}$

The OIAJ proposal as modified also fails to address the problem of identifying injured parties in the public action procedure and absentee class members in class compensatory procedures. In a public action, the question is whether the cost of compiling a list of the names and addresses of persons to whom a recovery notice is to be sent is to be charged against the public recovery fund, especially where the defendant actually performs the identification task. In a class compensatory action, the question arises whether identification is simply part of the notice process, and thus an expense ordinarily borne by the plaintiff, or whether a different approach is appropriate. Notwithstanding the Supreme Court's conclusion in Oppenheimer that identification of class members is part and parcel of Rule 23(c)(2) notice, and not part of the subject matter of the litigation, ${ }^{182}$ the public action and class coinpensatory procedures could include a more flexible standard, modeled either after Rule 26(c) or an ad hoc approach based on the ease with wliiclı one party or the other might perform the required tasks. Such

179. S. $3475 \S 3021(\mathrm{a})(2)$.

180. Id. $\S 3013$.

181. See text accompanying notes 114-15 supra.

182. 437 U.S. at 359. 
an approach would avoid always placing on the plaintiff the burden and expense of identification, particularly where the necessary inforination is contained in the records of a party opposing the action. ${ }^{183}$

\section{CONCLUSION}

The problems posed by the preliminary notice requirements of subdivision (c)(2) highlight the need for a new look at the (b)(3) class action procedure. While reading the scope of Rule 23 and of the notice provisions rather broadly, Oppenheimer confirms the imphications in Eisen that trial judges have only a narrow range of discretion when dealing with the problems posed by subdivisions (b)(3) and (c)(2). Insofar as it inflexibly places on (b)(3) plaintiffs the sometimes large burden of preliminary notice costs and raises the possibility of intrusions into a (b)(3) plaintiff's personal finances and relationship with counsel, the current approach to (c)(2) notice upsets the balance sought through Rule 23(b)(3) between, on the one hand, economy of litigation and umformity of decisions and, on the other, procedural fairness and avoidance of undesirable results. ${ }^{184}$ Admittedly, corporations must be protected agamst strike suits and from financing lawsuits against themselves, and judicial resources should not be needlessly taxed with the complexities of class hitigation. Nevertheless, the economies and other benefits of class actions should be made available to large groups of similarly situated injured persons whose individual stakes are too small to warrant individual lawsuits. As one observer has commented, "[n]otlimg is more destructive to a sense of justice than the widespread behef that it is much more risky for an ordinary citizen to take five dollars from one person at the point of a gun than it is for a corporation to take five dollars each from a million customers at the point of a pen." 185

D. Rhett Brandon

183. See text accompanying notes $36-38,57-58$ supra.

184. See text accompanying notes 8-13 supra.

185. 124 CoNG. ReC. S14,502 (daily ed. Aug. 25, 1978) (reinarks of Sen. DeConcini) (quoting Address by Vice President Mondale to the Second Judicial Circuit Conference (Sept. 10, 1977)). 
